\title{
OPTIONS OF LONG-TERM CONTRACEPTIVE METHODS IN MARRIED WOMEN IN SOUTH SULA WESI (ANALYSIS OF IDHS 2017)
}

\author{
Rahmawati Azis 1 , Akmal Mahmud ${ }^{2}$, Syahmida Syahbuddin Arsyad ${ }^{3}$ \\ ${ }^{1}$ Institute of Health Science (STIK) Tamalatea, Makassar, Indonesia \\ ${ }^{2}$ National Population and Family Planning Commission (BKKBN), South Sulawesi Province, Indonesia \\ ${ }^{3}$ Center for Research and Population Development, BKKBN, Jakarta, Indonesia \\ Corresponding Author: Rahmawati Azis \\ Email: rahmaazis@stiktamalateamks.ac.id
}

\begin{abstract}
The long-term contraceptive method is an effective method for preventing pregnancies. However, users of longterm contraceptive methods are considerably lower compared to those of non-long-term contraceptive methods in South Sulawesi. The research objective was to examine the determinants of choosing long-term contraceptive methods in South Sulawesi. This study used data from the 2017 Indonesia Demographic and Health Survey by analyzing 583 married women who were using contraception in South Sulawesi. A descriptive analysis was employed to estimate the prevalence of long-term contraceptive methods. Meanwhile, the Chi-square test and logistic regression analysis were used to identify the determinants of choosing long-term contraceptive methods. The results from the descriptive analysis showed about $18.9 \%$ of the sampled married women were long-term contraception users, among those were implant users (10.2\%). More married women with higher education and more parity chose to use it. The better the knowledge about the type of contraception, the greater the chance to use long-term contraceptive methods. Women who were told about side effects, sources of government services, and free fees were significantly influenced to use long-term contraception. Women who received staff visits and visited health facilities were less likely to choose the long-term methods. This implies that contact with field oMKJPlongterm contraceptive methodslong-term contraceptive methodsfficers has not been able to motivate prospective acceptors to use. Improved education and knowledge, especially about types of contraception and side effects, are needed to increase women's long-term contraception use alongside. The quality of services at free/subsidized costs also needs to be improved, and training should be given for capacity building, especially in communication skills, to family planning field officers.
\end{abstract}

Keywords: long-term contraceptive methods, knowledge, side effects, source of service, cost

\begin{abstract}
ABSTRAK
Metode kontrasepsi jangka panjang adalah metode yang efektif dalam mencegah kehamilan. Namun, penggunaan kontrasepsi jangka panjang masih rendah, dibandingkan dengan non-kontrasepsi jangka panjang, termasuk di Sulawesi Selatan. Penelitian bertujuan untuk mengetahui determinan memengaruhi pemilihan kontrasepsi jangka panjang di Sulawesi Selatan. Penelitian ini menggunakan data Survei Demografi dan Kesehatan Indonesia 2017 yang melibatkan 583 wanita berstatus kawin, pengguna kontrasepsi di Sulawesi Selatan. Data dianalisis secara deskriptif untuk memperkirakan prevalensi kontrasepsi jangka panjang. Sementara itu, analisis uji chi-square dan regresi logistik digunakan untuk mengidentifikasi penentu pilihan kontrasepsi jangka panjang. Hasil analisis deskriptif menunjukkan sekitar 18,9\% dari sampel wanita yang sudah menikah adalah pengguna metode jangka panjang dan di antaranya adalah pengguna susuk KB $(10,2 \%)$. Wanita kawin memilih menggunakan kontrasepsi jangka panjang lebih tinggi pada mereka yang memiliki paritas lebih banyak dan berpendidikan tinggi. Semakin baik pengetahuan mengenai jenis kontrasepsi, semakin besar peluang menggunakan kontrasepsi jangka panjang. Sumber layanan pemerintah dan biaya gratis signifikan memengaruhi pemilihan kontrasepsi jangka panjang. Wanita yang mendapatkan penyuluhan dari petugas dan mengunjungi fasilitas kesehatan memiliki peluang lebih kecil untuk memilih kontrasepsi jangka panjang. Hal ini menunjukkan bahwa kontak dengan petugas belum maтри memotivasi calon pengguna kontrasepsi jangka panjang. Peningkatan pendidikan dan pengetahuan, khususnya tentang jenis kontrasepsi dan efek samping, perbaikan kualitas pelayanan dengan biaya gratis/subsidi dan pelatihan terutama terkait kemampuan dan keterampilan komunikasi petugas lapangan KB diperlukan, sehingga partisipasi wanita dalam menggunakan kontrasepsi jangka panjang akan semakin meningkat.
\end{abstract}

Kata kunci: kontrasepsi jangka panjang, pengetahuan, efek samping, sumber pelayanan, biaya 


\section{INTRODUCTION}

The family planning program has an important role in reducing the population growth rate/laju pertumbuhan penduduk (LPP) and total fertility rate (TFR). The main objectives of family planning services are to improve maternal and child health, prevent maternal and infant mortality, fulfill reproductive rights, as well as regulate pregnancy schedules, number of children, and ideal pregnancy intervals as desired.

Indonesia's family planning program started in the early 1970s, has succeeded in reducing fertility and maternal mortality. The IDHS data show that $63.6 \%$ of married women used a contraceptive method in 2017. Despite the high prevalence of contraceptive use in Indonesia, it was reported that $8.1 \%$ of pregnancies were unplanned and $7.1 \%$ were unwanted. Unwanted pregnancies in Indonesia are associated with high parity and older women. The government recommends the long-term method because it is one of the targeted methods in Indonesia's 2020-2024 mid-term development plan (National Population and Family Planning Commission, 2018; National Population and Family Planning Commission, 2020).

One of the reasons the proportion of nonlong-term contraceptive methods is higher is because the users consider this method to be cheaper than long-term contraceptive methods. However, the dropout rate for the users of nonlong-term contraceptive methods is higher. In the end, this can contribute to the failure of the population growth control program.

In the first year, long-term contraception (implant and IUD) has a higher continuation rate (83-88\%) and this method is an excellent solution for delaying pregnancy for a longer time (Peipert et al., 2011). However, despite the efficacy and acceptance of long-term contraceptive methods, its use is still low in Indonesia.

The targets set out in the National Population and Family Planning Commission Strategic Plan include increasing the prevalence of long-term contraception users in Indonesia by $23.1 \%$ (2019) and $25.1 \%$ (2020) until reaching 28.4\% in 2024 (National Population and Family Planning Commission, 2020). However, in 2017, the achievement of long-term contraceptive methods in Indonesia only reached $13.4 \%$. Especially in South Sulawesi, the number of long-term contraception users was much lower at only 10.4\% (National Population and Family Planning Commission, 2018).

The use of long-term contraceptive methods among married women aged 15-49 years in South Sulawesi, from 2002-2003 to 2012 has decreased continuously, from $5.7 \%$ in $2002-03$ to $4.9 \%$ (in 2012), but began to increase in 2017 by $10.4 \%$. This is similar to the condition of Indonesia on the whole, although the percentage of long-term contraceptionusers in South Sulawesi is lower than Indonesia on average (Graph 1).

Previous research has documented various factors that can influence the choice of long-term contraceptive methods. Demographic traits such as age (Harzif et al., 2019; Adedini, Omisakin and Somefun, 2019; Bhandari et al., 2019), profession (Fekadu et al., 2019; Adedini, Omisakin, and Somefun, 2019), riches (Fekadu et al., 2019; Adedini, Omisakin, and Somefun, 2019; Bhandari et al., 2019), number of children (Fitrianingsih and Melaniani, 2016; Tibaijuka et al., 2017; Adedini, Omisakin, and Somefun, 2019; Bhandari et al., 2019), child wishes (Bhandari et al., 2019), education (Secura and McNicholas, 2013; Adedini, Omisakin, and Somefun, 2019), knowledge (Tibaijuka et al., 2017), side effects (Ontiri et al., 2019), family planning information through the media (Adedini, Omisakin, and Somefun, 2019), officer visits (Harzif et al., 2019), medical facilities (Triyanto and Indriani, 2018; Mario and Irma, 2020), service source (Triyanto and Indriani, 2018), cost (Secura and McNicholas, 2013; Tibaijuka et al., 2017; Adedini, Omisakin, and Somefun, 2019; Harzif et al., 2019), residence (Adedini, Omisakin, and Somefun, 2019).

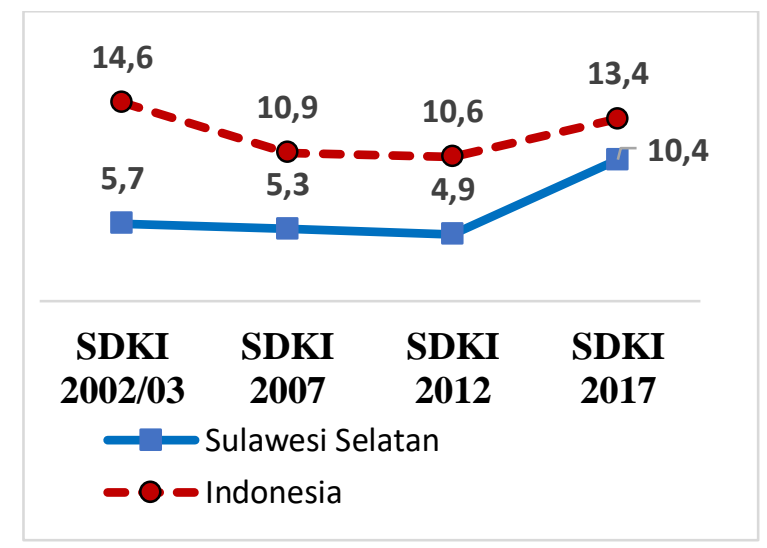

Graph 1. Trends in Using long-Term Contraceptive Methods according to the 2002/2003 - 2017 IDHS. 
This study aimed to identify the main determinants of the selection of long-term contraceptive methods among married women aged 15-49 years in South Sulawesi.

\section{METHODS}

The data in this analysis were sourced from the Demographic and Health Survey, a nationally representative household survey conducted every 5 years and conducted in 90 countries to provide data on population, health, and nutrition. The 2017 IDHS was the $8^{\text {th }}$ IDHS, held in collaboration with Central Bureau of Statistics, National Population and Family Planning Commission, and the Indonesian Ministry of Health. It was implemented with technical assistance from ICF through the Demographic and Health Surveys (DHS) project, namely the USAID program. The IDHS included national and provincial-level information on fertility, maternal health, child health, HIV/AIDS, and women's empowerment (National Population and Family Planning Commission, 2018). This study analyzed data from questionnaires for women aged 15-49 years. The sample data analyzed met the following inclusion criteria: (1) data were collected from the women's questionnaire in the 2017 IDHS as the latest IDHS; (2) women aged 15-49 years who were married or living with their partners; (3) women currently using contraception during the interview; (4) the study dataset covers the province of South Sulawesi. The sample was determined through a filter and data were clean to ensure the selected sample was in line with the research objectives. The sample data for analysis amounted to 583 people.

In the process, raw data from SDKI 2017 were used with the file name idir71fl. The Chisquare test was used for a bivariate analysis to determine the relationship between independent variables (age, education, occupation, wealth, number of children, the desire of children, knowledge of the fertile period, knowledge of contraception, side effects, information through the media, visits by officers, visiting health facilities, sources of services, costs, residence) with the choice of long-term contraception. To determine the factors associated with the selection of long-term contraceptive methods in a multivariable manner, it was tested by logistic regression. This model is suitable for assessing the effect of the long-term contraceptive methods election. All predictors were significant in the bivariable analysis, $\mathrm{p}<0.25$ was included in the initial logistic model. The final logistic model included only significant predictors $(\mathrm{p}<0.05)$ after adjusting for all confounders. The constant effect of the predictor on the likelihood of an outcome is expressed as the odds ratio (OR) at the $95 \%$ confidence interval.

\section{RESULTS}

The results of data analysis showed that the acceptors who used long-term contraceptive methods were 110 people $(18.9 \%)$, with nonlong-term contraception users at $66.9 \%$. The most common types of contraception used were injections (43.8\%) and pills (19.9\%). Meanwhile, the IUD, which is one of the non-hormonal longterm contraceptive methods, was only recorded at $3.6 \%$. The use of traditional methods was still quite high, namely $15.3 \%$, where the percentage of interrupted copulations (10.6\%) was still higher than the acceptors of implant at about $10.2 \%$ (Table 1).

Table 1. Use of Contraceptive Methods and Types in South Sulawesi

\begin{tabular}{lcc}
\hline Contraceptive Method & $\mathbf{n}$ & $\mathbf{\%}$ \\
\hline Long-term & & \\
\cline { 1 - 2 } Implant & $\underline{\mathbf{1 1 0}}$ & $\underline{\mathbf{1 8 . 9}}$ \\
IUD & 59 & 10.2 \\
MOW & 21 & 3.6 \\
MOP & 29 & 5.0 \\
\hline Non-long-term & 1 & 0.2 \\
\hline contraceptive methods & $\underline{\mathbf{3 9 0}}$ & $\underline{\mathbf{6 6 . 9}}$ \\
Inject & 256 & 43.8 \\
Pill & 116 & 19.9 \\
Male Condom & 14 & 2.4 \\
MAL & 4 & 0.7 \\
\hline Traditional & $\underline{\mathbf{1 0 3}}$ & $\underline{\mathbf{1 5 . 3}}$ \\
Intercourse Interrupted & 62 & 10.6 \\
Periodic Abstinence & 17 & 2.9 \\
Other Traditional & 4 & 0.7 \\
Amount & $\mathbf{5 8 3}$ & $\mathbf{1 0 0 . 0}$ \\
\hline Source: 2017 IDHS
\end{tabular}

Source: 2017 IDHS data

Most of the female acceptors were 35-49 years old $(56.8 \%)$, graduated from junior high school $(54 \%)$, not working $(35.8 \%)$, middle to lower wealth quintal (56.1\%), and had 2-3 children (56.6\%). Regarding the desire to become pregnant and give birth, the majority (57.5\%) stated that they did not want any more children.

Based on the level of knowledge about the fertile period, it is known that most of the 
female acceptors have the correct answer about the fertile period (54.5\%). Likewise with knowledge of contraception, it is enough to know the type of contraception. Approximately $70.5 \%$ knew 5-9 types of modern contraceptive tools/methods. Regarding family planning information, as many as $52 \%$ stated that they had never received any family planning information from the media in the last six months, and about $24 \%$ were informed about side effects. Meanwhile, around 93\% stated that they had never been visited by a health/family planning officer in the last six months. Regarding visits to health facilities, around $53.3 \%$ stated that they had visited health facilities in the last six months. When viewed from the source of family planning services, $41.4 \%$ received it from the government.

Table 2 shows the results of bivariable analysis, the significant factors related to the choice of using long-term contraceptive methods in South Sulawesi for married women of childbearing age were age, number of children, desire to have more children, education, knowledge of contraception, being informed of side effects, visiting health facilities, source of services, and cost.

The results of the multivariable analysis showed that the factors that influenced the selection of long-term contraceptive methods were the number of children (less than 2 and more than 3), education (junior high school graduates and below), knowledge of contraception, being informed of side effects, visits by officers, visiting health facilities, sources of government services, and costs. Education, visits by officers, visiting health facilities, and costs had a negative influence on the choice of using long-term contraceptive methods (Table 3 ).

Judging from the number of children, women with more than 3 children tended to use long-term contraceptive methods three times more compared to those with $<2$ children. Based on the level of education, the use of long-term contraceptive methods was higher in women who graduated from elementary school $(26 \%)$. The lowest proportion of long-term contraception users was in junior high school graduates $(14.9 \%)$ and tended to increase among high school graduates $(22.6 \%)$. Looking at the negative parameter estimates, it can be stated that the tendency to choose long-term contraceptive methods decreased with increasing education levels.

There is a relationship between contraceptive knowledge and the selection of long-term contraceptive methods. The higher the level of knowledge, the greater the tendency to use long-term contraceptive methods. Women who know the type of contraception well and enough have seven and four times the chance to use long-term contraceptive methods, respectively, compared to those with less knowledge. Meanwhile, women who had been told about side effects had almost three times the chance of using long-term contraceptive methods compared to those who had never been told.

In the last six months, the proportion of officers who visited houses was lower for women who used long-term contraceptive methods. The results of the beta parameter were negative, meaning that the tendency of women visited by officers to choose long-term contraceptive methods was lower than women who were not visited by officers. The same thing also happened to those who visited health facilities and had a negative (inversely proportional) effect on the selection of long-term contraceptive methods.

The use of long-term contraceptive methods is also influenced by the source of family planning services and their costs. Users who served in government service places had almost four times the chance to use long-term contraceptive methods compared to other private/other service sources. Women who disclose the costs incurred to obtain family planning services had a lower chance of using long-term contraceptive methods. The negative value of the beta estimate indicates that the cost factor prevents women from choosing to use long-term contraceptive methods.

\section{DISCUSSION}

Among the modern contraceptive methods in the last three decades, the most used are injectable and pill contraceptives. The target of achieving long-term contraception is very important to achieve the prevalence rate of modern contraception by 2024 , as stated in the Indonesian Medium-Term National Development Plan 2020-2024, at a goal of 63.4\% (National Population and Family Planning Commission, 2020).

This study shows that only a few South Sulawesi women use long-term contraception to delay and terminate their pregnancies. Women want to get pregnant again soon after the birth of their first child and there is high value of child ownership in South Sulawesi. It is important to provide comprehensive and accurate information and counseling about the effectiveness, safety, 
Table 2. Socio-Demographic Characteristics of Contraceptive Users in South Sulawesi

\begin{tabular}{|c|c|c|c|c|c|c|c|}
\hline \multirow[t]{2}{*}{ Variables } & \multicolumn{2}{|c|}{$\begin{array}{l}\text { Long-Term } \\
\text { Contraceptive } \\
\text { Methods }\end{array}$} & \multicolumn{2}{|c|}{$\begin{array}{c}\text { Other } \\
\text { Contraceptives }\end{array}$} & \multicolumn{2}{|c|}{ Amount } & \multirow[t]{2}{*}{ P-value } \\
\hline & $\mathbf{n}$ & $\%$ & $\mathbf{n}$ & $\%$ & $\mathbf{n}$ & $\%$ & \\
\hline \multicolumn{8}{|l|}{ Age (Years) } \\
\hline $15-19$ & 1 & 7.1 & 13 & 92.9 & 14 & 2.4 & \multirow{3}{*}{0.001} \\
\hline $20-34$ & 29 & 12.2 & 209 & 87.8 & 238 & 40.8 & \\
\hline $35-49$ & 80 & 24.2 & 251 & 75.8 & 331 & 56.8 & \\
\hline \multicolumn{8}{|l|}{ Work } \\
\hline Does not work & 33 & 15.8 & 176 & 84.2 & 209 & 35.9 & \multirow{3}{*}{0.246} \\
\hline Agriculture & 39 & 22.5 & 139 & 77.5 & 178 & 30.5 & \\
\hline Other & 38 & 19.4 & 158 & 80.6 & 196 & 33.6 & \\
\hline \multicolumn{8}{|l|}{ Riches } \\
\hline Middle down & 62 & 19.0 & 265 & 81.0 & 327 & 56.1 & \multirow{3}{*}{0.138} \\
\hline Intermediate & 15 & 13.3 & 98 & 86.7 & 113 & 19.4 & \\
\hline Middle to upper & 33 & 23.1 & 110 & 76.9 & 143 & 24.5 & \\
\hline \multicolumn{8}{|l|}{ Number of children } \\
\hline$<2$ & 15 & 11.6 & 114 & 88.4 & 129 & 22.1 & \multirow{3}{*}{0.000} \\
\hline $2-3$ & 49 & 14.9 & 281 & 85.1 & 330 & 56.6 & \\
\hline$>3$ & 46 & 37.1 & 78 & 62.9 & 124 & 21.3 & \\
\hline \multicolumn{8}{|c|}{ Intention for childbearing } \\
\hline Do not want any more & 75 & 22.4 & 260 & 77.6 & 335 & 57.5 & \multirow{2}{*}{0.022} \\
\hline Still want kids & 35 & 14.1 & 213 & 85.9 & 248 & 42.5 & \\
\hline \multicolumn{8}{|l|}{ Education } \\
\hline Elementary school & 18 & 26.1 & 51 & 73.9 & 69 & 11.9 & \multirow{3}{*}{0.017} \\
\hline Junior school graduated & 47 & 14.9 & 268 & 85.1 & 315 & 54.0 & \\
\hline High school graduated & 45 & 22.6 & 154 & 77.4 & 199 & 34.1 & \\
\hline \multicolumn{8}{|c|}{ Knowledge of Fertile Period } \\
\hline Right & 60 & 18.9 & 258 & 81.1 & 318 & 54.5 & \multirow{2}{*}{1.000} \\
\hline Wrong & 50 & 18.9 & 215 & 81.1 & 265 & 45.5 & \\
\hline \multicolumn{8}{|c|}{ Contraceptive Knowledge } \\
\hline Less $(\leq 4)$ & 4 & 5.0 & 76 & 95.0 & 80 & 13.7 & \\
\hline Enough (5-9) & 82 & 20.0 & 329 & 80.0 & 411 & 70.5 & 0.001 \\
\hline Good $(\geq 10)$ & 24 & 26.1 & 68 & 73.9 & 92 & 15.8 & \\
\hline Be Notified of Side Effe & & & & & & & \\
\hline Never & 66 & 15.1 & 377 & 84.9 & 443 & 76.0 & \\
\hline Yes I have & 44 & 31.4 & 96 & 68.6 & 140 & 24.0 & 0.000 \\
\hline Family Planning Inforr & on Via & edia & & & & & \\
\hline No & 60 & 19.8 & 243 & 80.2 & 303 & 52.0 & \\
\hline Yes & 50 & 17.9 & 230 & 82.1 & 280 & 48.0 & 0.622 \\
\hline Officer Visit & & & & & & & \\
\hline No & 17 & 19.8 & 434 & 80.2 & 541 & 92.8 & \\
\hline Yes & 3 & 7.1 & 39 & 92.9 & 42 & 7.2 & 0.070 \\
\hline Visiting Health Faciliti & & & & & & & \\
\hline No & 61 & 22.4 & 212 & 77.6 & 273 & 46.7 & \\
\hline Yes & 49 & 15.8 & 261 & 84.2 & 310 & 53.3 & 0.054 \\
\hline Service source & & & & & & & \\
\hline Private/Other & 33 & 9.6 & 309 & 90.4 & 342 & 58.7 & \\
\hline Government & 78 & 32.4 & 163 & 67.6 & 241 & 41.3 & 0.000 \\
\hline Cost & & & & & & & \\
\hline There is not any & 70 & 35.4 & 128 & 64.6 & 198 & 34.0 & 0000 \\
\hline There is & 40 & 10.4 & 345 & 89.6 & 385 & 66.0 & 0.000 \\
\hline
\end{tabular}




\begin{tabular}{|c|c|c|c|c|c|c|c|}
\hline \multirow[t]{2}{*}{ Variables } & \multicolumn{2}{|c|}{$\begin{array}{l}\text { Long-Term } \\
\text { Contraceptive } \\
\text { Methods }\end{array}$} & \multicolumn{2}{|c|}{$\begin{array}{c}\text { Other } \\
\text { Contraceptives }\end{array}$} & \multicolumn{2}{|c|}{ Amount } & \multirow[t]{2}{*}{ P-value } \\
\hline & $\mathrm{n}$ & $\%$ & $\mathrm{n}$ & $\%$ & $\mathbf{n}$ & $\%$ & \\
\hline \multicolumn{8}{|l|}{ Residence } \\
\hline Urban & 35 & 18.3 & 156 & 81.7 & 191 & 32.8 & \multirow{3}{*}{0.804} \\
\hline Rural & 75 & 19.2 & 317 & 80.8 & 392 & 67.2 & \\
\hline Amount & 110 & 18.9 & 473 & 81.1 & 583 & (100.0) & \\
\hline
\end{tabular}

Source: 2017 IDHS data

Table 3. The Main Determinants of long-term contraceptive methods Selection for Married Women (15-49 Years Old) in South Sulawesi

\begin{tabular}{|c|c|c|c|c|}
\hline Variable & $\begin{array}{c}\text { Beta } \\
\text { Parameters }\end{array}$ & Adjusted OR & $95 \% \mathrm{CI}$ & P-value \\
\hline \multicolumn{5}{|l|}{ Number of children } \\
\hline$<2$ & & & & 0.001 \\
\hline $2-3$ & 0.149 & 1.160 & $0.582-2.313$ & 0.672 \\
\hline$>3$ & 1.148 & 3.151 & $1.482-6.699$ & 0.003 \\
\hline \multicolumn{5}{|l|}{ Education } \\
\hline Elementary school & & & & 0.025 \\
\hline Junior school graduated & -0.884 & 0.413 & $0.191-0.892$ & 0.024 \\
\hline High school graduated & -0.293 & 0.746 & $0.324-1.718$ & 0.491 \\
\hline \multicolumn{5}{|c|}{ Contraceptive Knowledge } \\
\hline Less $(\leq 4)$ & & & & 0.008 \\
\hline Enough (5-9) & 1.379 & 3.970 & $1.319-11.943$ & 0.014 \\
\hline Good $(\geq 10)$ & 1.986 & 7.287 & $2.082-25.502$ & 0.002 \\
\hline \multicolumn{5}{|c|}{ Be Notified of Side Effects } \\
\hline Never & & & & \\
\hline Yes I have & 1.004 & 2.729 & $1.565-4.760$ & 0.000 \\
\hline \multicolumn{5}{|l|}{ Officer Visit } \\
\hline \multicolumn{5}{|l|}{ No } \\
\hline Yes & -1.742 & 0.175 & $0.046-0.664$ & 0.010 \\
\hline \multicolumn{5}{|l|}{ Visiting Health Facilities } \\
\hline \multicolumn{5}{|l|}{ No } \\
\hline Yes & -0.555 & 0.574 & $0.347-0.949$ & 0.031 \\
\hline \multicolumn{5}{|l|}{ Service Source } \\
\hline \multicolumn{5}{|l|}{ Private/Other } \\
\hline Government & 1.353 & 3.869 & $2.285-6.551$ & 0.000 \\
\hline \multicolumn{5}{|l|}{ Cost } \\
\hline $\begin{array}{l}\text { There is not any } \\
\text { There is }\end{array}$ & -1.375 & 0.253 & $0.152-0.420$ & 0.000 \\
\hline
\end{tabular}

Source: 2017 IDHS data

and accessibility of long-term methods, especially IUD and implants contraception in subsequent fertility.

The results of this study indicate that the more children they have, the higher the tendency to use long-term contraceptive methods. This is consistent with research by Adedini, Omisakin, and Somefun (2019), which also found that the greater the number of children, the greater the chance of using the long-term method. Research
Bhandari et al., (2019), Tibaijuka et al. (2017), and Fitrianingsih and Melaniani (2016) found that parity affects the choice of contraceptives, where mothers with $\geq 3$ children tended to use long-term contraceptive methods contraception more than those with parity $<3$ children.

The low use of long-term contraceptive methods among nulliparous women (who have not had children), is evident in many studies, even though they have no medical contraindications to 
using contraceptive methods. Multiparous women are more likely to use long-term contraceptive methods than women without children (Adedini, Omisakin, and Somefun, 2019).

Women who had less than two children had a lower proportion of using long-term contraception. Women who had parities were more likely to stop fertility; therefore, they prefer long-term contraceptive methods. Young women who have only had one child have less experience in choosing contraception than women with many children. The choice of type of contraception is usually difficult for primiparous women (first child) compared to multiparous women who mostly have understanding and experience in the selection of contraception.

Research by Gibbs et al. (2016) showed that training interventions for clinical officers proved to affect knowledge, counseling, and clinical skills, to improve counseling and access to reversible long-term contraceptive methods, especially for nulliparous women.

There were differences in the use of the long-term contraceptive methods method based on the level of education. The use of longterm contraceptive methods was higher in women who graduated from elementary school. The lowest proportion was in junior high school education and tended to increase among high school graduates. A plausible reason for this is women with a high school education have a better understanding of the benefits of longterm contraceptive methods and are more likely to be willing to pay for contraception to prevent pregnancy. Meanwhile, those with basic education tend to use long-term contraceptive methods, such as implants for family planning, because of free assistance from the government.

The results of this study were almost the same as the research results by Hajar (2018), which indicate that the factor that contributed to a high chance of using the IUD was higher education. Whereas Sari (2020), who analyzed the use of modern contraception (all types), in women in Indonesia had different results. The result states that education harms the use of modern contraception. The higher the education of Indonesian women, the lower the use of modern contraception.

An important contribution in generating maternal interest in the choice of contraception is knowledge about contraception. Knowledge can be the basis for acceptance from family planning officers before mothers are interested and decide in choosing to use long-term contraceptive methods. Correct knowledge of various types of contraception will increase the chances of participation in family planning programs, including long-term methods. Mothers who know the types of contraception well and adequately are more likely to use long-term contraceptive methods than those with less knowledge.

The results of the relevant research also found that there was a relationship between knowledge of long-term contraceptive methods and interest of the users in using long-term contraceptive methods, where mothers with knowledge of long-term contraceptive methods tended to be interested in using long-term contraceptive methods. Someone who knows about contraception is more confident and comfortable when choosing to use long-term methods (Assagaff, 2018).

In the long-term contraceptive methods type indicator, there were still women who have inadequate knowledge. This needs to be straightened out through Information Educational and Communication (IEC) from the family planning officer. Some women choose not to use long-term contraceptive methods because of wrong beliefs. Other studies have also shown that available long-term methods have not been fully accepted due to a lack of knowledge among women of reproductive age (Tibaijuka et al., 2017).

Clear and complete information, including the side effects of family planning by officers, will strengthen the choice of using longterm contraceptive methods. Family planning service officers provide quality services where they help choose and ensure that the choice is correct and safe. Women who had been told about side effects are more likely to use long-term contraceptive methods compared to those who had never been told about side effects. Providing accurate information to women about the side effects of various contraceptive methods can improve adherence to contraceptive methods, including long-term methods.

The use of long-term contraceptive methods is also influenced by the source of family planning services. Sources of family planning services are determined by the fulfillment of service standards, such as adequate infrastructure. Married women of childbearing age are more likely to choose the source of government facilities for family planning 
services than private/other facilities. Further analysis proves that long-term contraceptive methods acceptors have a higher proportion of using government services than private/other services. In multivariable analysis, the source of government services had a significant effect on long-term contraceptive use. Contraceptive users who were served at government service facilities had almost four times the chance to use long-term contraceptive methods compared to other/private service sources.

Dominant acceptors use government services, such as community health centres (Puskesmas), because they are the first health facility that provides health social security agency (BPJS) services. There is a certain schedule in serving the family planning program, which allows them to more easily arrange and adjust the existing schedule. The research of Triyanto and Indriani (2018) stated that the selection of long-term contraceptive methods is also influenced by the public trust when choosing contraceptive services. For example in a hospital, the community believes that the medical equipment is more adequate, the qualifications of family planning officers are better, and the facilities are more secure and complete. Good services and accessible access can increase interest in using contraception, especially longterm contraceptive methods.

Those who visited health facilities in the last six months had a lower proportion of choosing long-term contraceptive methods than those who did not come to health facilities. It is interesting because this finding proves that those who visited health facilities affected (inversely) their choice of using long-term contraception. The reason for this is that women of childbearing age visit health services, not just to get family planning services. This may also indicate that those who visit health facilities have not received adequate information regarding the long-term method. Opportunities to provide IEC, especially the choice of longterm contraceptive methods when visiting health facilities, should be increased. Research by Mario and Irma (2020) revealed that the most neglected aspect in public (government) facilities are access to information on contraceptive options, while 'follow-up and sustainability mechanisms' are most neglected in private health facilities.

As for information regarding visits by field officers, only about $7 \%$ admitted that there had been visits by family planning field officers in the last six months. These findings are important for future family planning programs. The interesting thing from the analysis of the proportion of users choosing long-term contraceptive methods for women who were successfully visited by family planning officers was lower than women who had no visits from the officers. It is possible that those visited by field officers did not receive comprehensive family planning information and adequate counseling about long-term contraceptive methods, and they did not choose long-term contraception as the appropriate method of contraception.

Lack of knowledge about the long-term contraceptive methods method reflects a lack of training for health workers on how to properly educate clients (acceptors) (Tibaijuka et al., 2017). Therefore, communication skills and motivational techniques for field officers need to be improved to conduct counseling. Competent field workers are very important to promote family planning programs, especially when it comes to long-term contraception because they are at the forefront of working with other community members such as family planning cadres. Other research findings show the importance of disseminating information through family planning officers about contraceptive methods (Harzif et al., 2019).

An overview of research results by Wahyuddin (2017) in Ujung Pandang, Makassar, found that family planning officers in socializing the family planning program through long-term contraceptive methods were following their roles as extension workers, motivators, movers, catalysts, facilitators, and role models. Improving the quality of staff resources is carried out through monthly training for field extension workers and family planning cadres. The Sub PPKBD were involved in activities such as conducting socialization of long-term contraceptive methods without forcing. Client can be taken directly to community health centres, but if they are willing to wait for mobile family planning services, the officer will record their name and before service, re-socialization is carried out and no fees are charged to the community. In this study, researchers have not found evidence of long-term planning for one year at the family planning center, but there was only operational planning(Wahyuddin, 2017).

Analysis by Ulya and Mahmudah (2020) estimated new family planning participants using the decomposition method, would cause the number to decrease. The researcher recommends 
the need for regular training for family planning officers and increasing the number of IEC activities in the target area.

Nurhajati (2018) found that the results of the competency test for family planning instructors in East Java showed that $62 \%$ still needed follow-up for competency development because they were not up to standard. This finding is not much different from the condition of family planning extension officers in South Sulawesi. Analysis results by Mahmud (2020) revealed from the distribution of the results of the PLKB/PKB competency exams in 2019, that more than half (68.4\%) needed follow-up development. Previously in 2017/2018, the percentage was very high (90.3\%), which required follow up. Competency results are marked by the high percentage of test results that do not meet the standards and need follow-up, this can have an impact on the quality of IEC for family planning officers during visits. It is hoped that the visit of officers will further increase the understanding, awareness, and motivation of client to use contraception and prioritize choosing long-term contraceptive methods.

A study by Gayatri (2020) explains about analyzing women throughout Indonesia using the 2017 IDHS data, which showed that women who were visited by field workers had a higher chance of using long-term reversible contraceptive methods than women who were not visited. However, the proportion of women visited by the field workers was less than $4 \%$.

Women who disclosed that there were costs involved in obtaining family planning services had a lower chance of using long-term contraceptive methods than those who perceived that there were no high costs. The cost factor prevents women from choosing to use long-term contraceptive methods. The low understanding of costs when measured in terms of long-term, effective, and efficient use of long-term contraceptive methods, is the reason why women prefer non-long-term contraceptive methods.

Relevant to this research, Septalia and Puspitasari (2016) stated that the majority of family planning acceptors also had the perception that long-term contraceptive methods was more expensive, and that non-long-term contraceptive methods was cheaper. If the use of contraception was calculated from an economical point of view, the use of 1 ong-term contraceptive methods is cheaper. Mothers' perception tends to focus on the costs incurred when first using it, regardless of the cost saved in the long term of its use. For example, the IUD and implants can be effective for a range of more than 3-8 years, even a tubectomy/vasectomy can last a lifetime. Meanwhile, the effectiveness of nonlong-term contraceptive methods is only a few months.

Sedgh and Hussain (2014) stated the main reasons for married women experiencing an unmet need for family planning was due to the lack of access, including high costs and very long distances. This is in line with research by Azis et al. (2016), which also revealed that the level of welfare was significantly related to the unmet need for family planning. Mothers who came from poor families were more likely not to use contraception. As Henke, Martins, and Boraas (2020) stated, the high cost of long-term contraceptive methods is the main barrier for lowincome women to choose the contraceptive.

\section{CONCLUSION AND SUGGESTION}

\section{Conclusion}

Factors that influence the choice of using long-term contraceptive methods are the number of children, education, contraceptive knowledge, being informed about side effects, visits by officers, visiting health facilities, sources of services, and costs. Women with higher parity tend to decide to use long-term contraceptive methods because it is more effective and the duration of use is longer. Women who are educated, knowledgeable about the types of contraception well, and informed of side effects, are more likely to use long-term contraception. Women who are visited by field officers and visit health facilities are less likely to use long-term contraceptive methods. This provides information that the competence of field officers is still low. Sources of services at government facilities are the choice for using long-term contraceptive methods and cost is one of the factors causing the low use of long-term contraceptive methods.

\section{Suggestion}

To increase women's participation in using long-term contraception, knowledge, especially on the types and side effects, must be increased. This should be done by improving women's education through compulsory education, as well as instilling the value of future responsibility with the millennial spirit. It is necessary to increase the quantity and quality of 
training and ommunication skills for family planning officers, especially in motivational and counseling techniques. There is the need to increase the availability of long-term contraceptive methods according to the needs of government service sources and further improve quality services at affordable/free/subsidized costs. Every visit by women of childbearing age to health facilities should include IEC about longterm contraception, especially the benefits and side effects.

\section{REFERENCES}

Adedini, S.A., Omisakin, O.A. and Somefun, O.D., 2019. Trends, Patterns and Determinants of Long-Acting Reversible Methods of Contraception among Women In Sub-Saharan Africa. PLOS ONE, 14(6), p.e0217574.

Assagaff, S.N.R., 2018. Hubungan Tingkat Pengetahuan Akseptor Wanita Tentang MKJP dengan Minat Pemilihan Metode Kontrasepsi di Puskesmas Tegalrejo Yogyakarta. Yogyakarta.

Azis, R., Syafar, M., Zulkifli, A. and Seweng, A., 2016. Effect of Family Wealth and Attitudes toward Unmet Need for Family Planning Among Fertile Couples in Makassar, South Sulawesi, Indonesia. International Journal of Sciences: Basic and Applied Research (IJSBAR). [online] Available at: <https://www.semanticscholar.org/>.

Bhandari, R., Pokhrel, K.N., Gabrielle, N. and Amatya, A., 2019. Long Acting Reversible Contraception Use and Associated Factors among Married Women of Reproductive Age in Nepal. PLoS ONE, 14(3), pp.1-13.

Fekadu, G.A., Omigbodun, A.O., Roberts, O.A. and Yalew, A.W., 2019. Factors Associated With Long Acting and Permanent Contraceptive Methods Use in Ethiopia. Contraception and Reproductive Medicine, 4(1), pp.1-11.

Fitrianingsih, A.D.R. and Melaniani, S., 2016. Faktor Sosiodemografi yang Memengaruhi Pemilihan Metode Kontrasepsi. Jurnal Biometrika dan Kependudukan, 5(1), pp.10-18.

Gayatri, M., 2020. The Utilization of LongActing Reversible Contraception and Associated Factors Among Women in Indonesia. 12(3), pp.110-120.
Gibbs, S.E., Rocca, C.H., Bednarek, P., Thompson, K.M.J., Darney, P.D. and Harper, C.C., 2016. Long-Acting Reversible Contraception Counseling and Use for Older Adolescents and Nulliparous Women. Journal of Adolescent Health.

Hajar, M., 2018. Determinan Penggunaan Metode Kontrasepsi IUD pada PUS di Wilayah Kerja Puskesmas Pontap Kota Palopo. Skripsi. Makassar: Universitas Hasanuddin.

Harzif, A.K., Lovita, B.T., Mariana, A., Malik, D.M. and Silvia, M., 2019. Factors Associated with The Utilization of LongActing Reversible Contraceptives among Family Planning Clients at The Pameungpeuk Rural Hospital , Indonesia [version 2; peer review: 2 approved] Achmad Kemal Harzif. F1000Research 2019, 7:1891, 7(1819), pp.1-14.

Henke, L., Martins, S. and Boraas, C., 2020. Barriers to Obtaining Long-Acting Reversible Contraception Among LowIncome Women [09I]. Obstetrics \& Gynecology, 135, p.94S.

Mahmud, A., 2020. Analisis Tenaga PKB/PLKB Hasil Remedial Ujian Kompetensi Provinsi Sulawesi Selatan Tahun 2019. Makassar.

Mario, E. and Irma, A., 2020. Quality of Care in Modern Contraceptive Service Delivery in the Public and Private Sector: A Cross Sectional Study in Indonesia. Global Journal of Health Science, 12(7), p.102.

National Population and Family Planning Commission, 2018. Survei Demografi dan Kesehatan Indonesia 2017. National Population and Family Planning Commission, Central Bureau of Statistics, Ministry of Health, USAID.

National Population and Family Planning Commission, 2020. Rencana Strategis BKKBN 2020-2024.

Nurhajati, W.A., 2018. Peningkatan Kompetensi Penyuluh Keluarga Berencana Provinsi Jawa Timur Melalui Diklat Berbasis ELearning. In: The ICECRS. pp.183-196.

Ontiri, S., Ndirangu, G., Kabue, M., Biesma, R. and Stekelenburg, J., 2019. Long-Acting Reversible Contraception Uptake and Associated Factors among Women of Reproductive Age in Rural Kenya. pp.1-11. 
Peipert, J.F., Zhao, Q., Allsworth, J.E., Petrosky, E., Madden, T., Eisenberg, D. and Secura, G., 2011. Continuation and satisfaction of reversible contraception. Obstetrics and Gynecology, 117(5), pp.1105-1113.

Sari, D.N., 2020. Sex Preference on Child and Modern Contraception Use in Fertile Age Women in Indonesia (Analysis of IDHS 2017). 9(July), pp.77-86.

Secura, G.M. and McNicholas, C., 2013. LongActing Reversible Contraceptive Use Among Teens Prevents Unintended Pregnancy: A look at The Evidence. Expert Review of Obstetrics and Gynecology, 8(4), pp.297-299.

Sedgh, G. and Hussain, R., 2014. Reasons for Contraceptive Nonuse among Women Having Unmet Need for Contraception in Developing Countries. Studies in Family Planning, 45(2), pp.151-169.

Septalia, R. and Nunik Puspitasari, 2016. Faktor yang Memengaruhi Pemilihan Metode Kontrasepsi. Jurnal Biometrika dan Kependudukan, 5(2), pp.91-98.
Tibaijuka, L., Odongo, R., Welikhe, E., Mukisa, W., Kugonza, L., Busingye, I., Nabukalu, P., Ngonzi, J., Asiimwe, S.B. and Bajunirwe, F., 2017. Factors influencing Use of Long-Acting Versus Short-Acting Contraceptive Methods among Reproductive-Age Women In A Resource-Limited Setting. pp.1-13.

Triyanto, L. and Indriani, D., 2018. Faktor yang Mempengaruhi Penggunaan Jenis Metode Kontrasepsi Jangka Panjang (MKJP) pada Wanita Menikah Usia Subur di Provinsi Jawa Timur. IJPH, 13(2), pp.244-255.

Ulya, D.I. and Mahmudah, 2020. Decomposition Method for Forecasting The Number of Participants of New Family Planning in Surabaya. Jurnal Biometrika dan Kependudukan, 9(1), pp.36-43.

Wahyuddin, N.R., 2017. Gambaran Penatalaksanaan Program KB Melalui Metode Kontrasepsi Jangka Panjang (MKJP) di Kecamatan Ujung Pandang Kota Makassar. Skripsi. Universitas Islam Negeri Alauddin Makassar. 